\title{
DEVELOPING FORENSIC ACCOUNTING CURRICULUM AT UNIVERSITIES
}

\author{
Jumansyah \\ Universitas Al Azhar Indonesia \\ jumansyah@uai.ac.id
}

\section{ARTICLE INFORMATION}

Article history:

Received July 31, 2015

Revised December 02, 2015

Accepted February 22, 2016

\section{JEL Classifications}

M49

\section{Key Words:}

Forensic accounting,

Fraud,

Accounting curriculum

\section{DOI:}

10.21532/apfj.001.16.01.01.08

\begin{abstract}
Accounting programs around the world have been revising their curriculum by including fraud / forensic accounting subject. This paper identifies the development of forensic accounting curriculum in the United States (US) and Indonesia. The first part of the paper is the model of forensic accounting curriculum development proposed by New Virgnia University. The second part of the paper presents the reality of forensic accounting subject in Indonesia. This paper is written to help accounting department consider introducing fraud / forensic accounting subject into its accounting program as well those who are revising their existing subjects.
\end{abstract}

\section{INTRODUCTION}

The world's ever occurred accounting scandals have triggered the fundamental changes in accounting practices. Audit / accounting scandals have actually occurred throughout the year in different parts of the world, with the greatest number in 2002. The most shocking thing is the scandal involving five major accounting firms or the big five (Djalil, 2014). The 2002's scandals include manipulation of financial statements (Enron, Adelphia, K Mart, Tyco), manipulation of sales presentation (AOL), manipulation of income presentation (Bristol-Myers Squibb), manipulation of sales value (CMS Energy, Duke Energy , Dynegy, El Paso Corporation), manipulation by decreasing profit (Freddie Mac), manipulation of cost charges (Halliburton), manipulation of revenue (Global Crossing), manipulation of payments recording (Merck \& Co.), conflict of interest (Merrill Lynch), manipulation of assets and liabilities 
(Mirant), and manipulation by increasing cash flow (WorldCom).

From 2000 to 2011, the majority of scandals occurred in the United States. The rest occurred in Belgium (Lernout \& Hauspie), Australia (One. Tel), Bermuda (Tyco), Italy (Parmalat), Canada (Nortel), Ireland (Anglo Irish Bank), India (Satyam Computer), and Japan (Olympus Corporation). Since the scandals had been planned and organized thoroughly, the data published did not reflect the quantity and quality of the real scandals.

The scandals are regrettable and condemned, but the disclosure of the scandals brings two benefits for the accounting profession and accounting practices; First, the issuance of the Sarbanes-Oxley Act (SOx) as a real response to the decline in investor confidence on a number of major corporate accounting scandals that led to loss of billions of US Dollars (Djalil, 2014). SOx binds all practitioners who are active in the capital market, provides a closer supervision over the financial practices in the capital market, provides additional responsibility of the Board of the Company until the criminal prosecution; Second, the birth of forensic accountant as a new branch of accounting profession (Davis et al., 2009). A report entitled "Serving Global Capital Markets and the Global Economy (The Global Report, 2006) concerns on the legal liability faced by accounting firms as a result of losses caused by fraud. The Global Report maintains the accounting profession, but opens a potential influx of forensic practices in accounting services. (Smith and Crumbley, 2009)
In a study conducted by American Institute of Certified Public Accountants (AICPA), the demand for forensic accounting is very high. The academic and practitioaner world have discussed the forensic accounting broadly, but there has been no clear definition formulation (Smith and Crumbley, 2009). Since it is still relatively new, broad definition formulation could still happen because the range of skills is broader than what is known in financial accounting and management accounting. The involvement of forensic accounting in the resolution of legal issues requires an accountant or auditor to master the unusual investigative techniques. (Jumansyah, 2014)

The high demand and the anticipation against the occurrence of new financial scandals are logical argument. Therefore, the forensic accounting should be a concern of both academics and practitioners. The academics through their active role at university have a very vital role in developing and deploying forensic accounting. So, it is very important for the academics to reproduce more study and research on forensic accounting.

This paper aims to describe the model of forensic accounting curriculum development conducted by West Virginia University (USA). The supporting data, in the form of real forensic accounting subjects in Indonesia, are described to determine the condition of forensic accounting curriculum development in Indonesia. This paper is expected to be useful for the study program of accounting in Indonesia and those who want to develop forensic accounting subject in their accounting curriculum. 


\section{THEORITICAL FRAMEWORK}

\section{Forensic Accounting at University}

Forensic accounting has beeen discussed continuously at universities. Davis et al. (2009) conducted a survey in which part of it examined what type of educational program that is in accordance with the science of forensic accounting. The surveys conducted on the academics, practitioners, and lawyers in the United States resulted in conclusion that forensic accounting should be held in graduate program or as part of undergraduate program, but it is not separated from the study program of accounting.

The same result can be seen in the research conducted by Jumansyah (2014) that uses the respondents of academics and practitioners of Audit Firms in Jakarta (Indonesia). The introduction to the relatively new science of forensic accounting is a constraint in accelerating the acceptance of forensic accounting as a separate discipline or which is held separately.

Efiong (2012) highlighted the difference in the progress of forensic accounting in developed countries and developing countries. In developing countries, the awareness of bachelor program students on forensic accounting is still very low, particularly in Nigeria as the object of his research. This result is certainly disappointing because the response of students or prospective students in Nigeria is not positive. There is a possibility that such a response is based on the ignorance of forensic accounting material.

\section{Pedagogical View of Forensic Accounting Curriculum}

Forensic accounting subject has been included in the study program of accounting around the world. However, the revisions carried out by the study program of accounting around the world have not found uniform formula yet. Smith and Crumbley (2009) identified the characteristics of three perspectives of the development of forensic accounting basic subject namely audit, fraud, and forensic and its implications in the accounting program. The results of their survey present identification of the approaches used in the development of forensic accounting subject. Their findings help to assist the subject developers in the future who consider including forensic accounting in accounting program, as well as the academics in revising their curriculum.

For accounting program, there is no specific answer that identifies the best pedagogical approach to be used in the curriculum development of fraud / forensic, but there is a philosophical belief about the best approach. The subject of traditional audit has presented financial instruction in the past accounting curriculum, and audit is a starting point in the development of fraud / forensic curriculum. However, the revision of the traditional auditbased content toward the approach of fraud / forensic curriculum has changed the scope of the analytical techniques used and understood in the revised curriculum. (Smith and Crumbley, 2009) 


\section{RESEARCH METHOD}

The research method used in this study is descriptive analysis of the possibility to develop forensic accounting curriculum at universities in Indonesia. The main references used are:

1. Report of West Virginia University (2007) funded by the US Department of Justice related to the forensic accounting education and training entitled "Education and Training in Fraud and Forensic Accounting: A Guide for Educational Institutions, Stakeholder Organizations, Faculty and Students".

2. Content of website on Master of Forensic Accounting, University of Wollongong Australia (www.uow.edu.au). This content only shows a simple curriculum development by comparing with the possible application at universities in Indonesian.

The report will be enriched with a description of the possible extension at universities in Indonesia.

The data used in this research are secondary data in the form of curriculum of undergraduate program in accounting available on the official website of the universities concerned. The data of universities obtained are from the ranking 1-50 of universities in Indonesia entitled "2015 University Web Ranking”, published in www.4icu.org. (Accessed on February 13, 2015)

\section{RESULT AND DISCUSSION}

\section{Development of Accounting Forensic Curriculum: Model of West Virginia}

In 2007, West Virginia University released a very important report on the education and training in accounting entitled "Education and Training in Fraud and Forensic Accounting: A Guide for Educational Institutions, Stakeholder Organizations, Faculty and Students". The report was funded by the US Department of Justice. The development of the report was actuall y done by the Technical Working Group of Accounting Education in Fraud and Forensic. The project itself aims to develop a model of accounting curriculum in fraud and forensic to assist academic institutions, public and private organizations, practitioners, lecturers, and students who are interested in becoming professional in forensic accounting.

The report mentions that there are main content areas in accounting forensic curriculum as follows:

1. Criminology, in particular those relating to the characteristics, dynamics and scope of fraud and financial crime; legal environment; and ethical issues.

2. Prevention, deterrence, detection, investigation and remediation of fraud.

a. Inappropriateness of assets, corruption, and misrepresentation.

b. Fraud in financial statements.

c. Forensic accounting in digital environment. 
3. Forensic advice and litigation services, including research and analysis, valuation of losses and damages, court investigation, and conflict resolution (including arbitration and mediation).

Prerequisite is the subject that should be taken by students to facilitate the understanding of forensic accounting. Some of the subjects referenced as a prerequisite are concept of basic accounting, concept of basic auditing, cycles of transaction processing and environment controlling, concept of business law, general business communication skills and business ethics, and basic computer skills.

The subject material introduced by West Virginia University (2007) may become a reference in the preparation of lecturing material in college. Here is the arrangement of subjects offered in forensic accounting curriculum development.

The large sections of the forensic accounting curriculum are criminology, forensic accounting, and forensic and litigation services. The elaboration of the three sections would be done as follows:

\section{Criminology; Legal, Regulatory, Enfironment of Professionals; dan Ethics.}

Criminology is a sociological study of crime and criminal. Understanding the characteristics, dynamics and scope of fraud and financial crime is an important aspect on the basis of a basic level of professional knowledge. The subject materials suggested include theories of the causes of crime and the application of the theory against whitecollar crime (West Virginia University, 2007).

By referring to the legal environment, the proposed range includes a comparison between criminal court and civil court, applied on fraud, the rights of individuals under investigation, and the rules of evidence. (West Virginia University, 2007)

Professionals in Forensic accounting must have an ethical framework for the adequate decision making. This takes some theories of business ethics and personal ethics code that can be applied so that the area of this specialization has been informed more clearly and understand the ethical expectations. Moreover, prospective students must be notified of the past inappropriate behavior, such as past criminal punishment, which can get them out of the profession. The students should also understand the protection for whistleblowers.

Knowledge of business law is a preliminary assumption to study the legal environment in the specialized area of forensic accounting. Traditional subjects in business law should be sufficient enough to achieve this level of understanding. (West Virginia University, 2007)

\section{Forensic Accounting}

The outcomes expected by the students, such as the placement opportunities and the employers' needs, shall determine the relative coverage of the subject areas. In 
general, forensic accounting is the core foundation of knowledge, skills, and abilities needed. Classroom instruction should include examples of forensic accounting engagements including theories testing and case studies. Students need to know the patterns and conditions around forensic accounting matters. (West Virginia University, 2007)

In connection with fraud, the students should know and understand the basic triangular of fraud: opportunity, pressure and rationalization. In addition, the students need to understand the key elements of fraud (action, secrets, and conversion), the symptoms, and the indications of fraud. Furthermore, the student should understand how to prevent the occurrence of the fraud victims (such as identity theft), the identification of measures to prevent the occurrence of the victim, when sacrificed, and know how to help remediate the situation. (West Virginia University, 2007)

\section{Forensic and Litigation Advisory Services}

The third group of subjects in forensic accounting curriculum is about the forensic and litigation advisory services. Professionals in Forensic and Litigation Advisory Services (FLAS) provide educational, technical, functional, and specialized industry services which are applied in the case of fraud in work, corruption, misuse, and fraud in financial statement. Professionals in FLAS can help lawyers by collecting financial information necessary to support (if recruited by the plaintiff) or weaken (if recruited by the defendant). They provide various supports, such as in special scope (analysis, datamining, documentation) and in broader approach (litigation strategy, arguments, testimony in civil and criminal cases), commitments in particular include investigation of claims of damages, matrimonial issues and the workplace, as well as the valuation of assets and businesses. (West Virginia University, 2007)

Forensic and litigation advisory services require interaction with lawyers through the engagement and excellent communication skills during the engagement and during the final stages of mediation, arbitration, negotiations, depositions, and / or testimony. Thus, communication skills (oral, pictorial / graphic, and written) are critical in the arena of forensic and litigation advisory services. Like the whole work of forensic accounting, there is an adversarial characteristic in the engagement, and the professionals can expect that their work will be scrutinized carefully. (West Virginia University, 2007)

From a pedagogical perspective, the study of forensic and litigation advisory services provides an excellent opportunity to develop top experience and to integrate skills development in the entire area of forensic accounting. (West Virginia University, 2007)

Basically, in the group of these subjects, 
the students should know the definition of forensic and litigation services, overview of services, research and analysis, damages, valuation, working papers, and reporting.

\section{Forensic Accounting Curriculum} Development: University of Wollongong

University of Wollongong Australia is one of the Universities that offer forensic accounting educational program. The educational program offered is Master level with the title of Master of Forensic Accounting (MForAccy) which becomes part of faculty of commerce. The length of study is one year and can be taken on a part-time by adjusting the time of graduation. The total number of semester credits that must be taken to pass is 48 .

Master of Forensic Accounting program emphasizes on forensic rather than controlbased or risk management approach to analyze the good corporate governance and the possibility of fraud. The students will be provided with extensive knowledge about the characteristics and the purposes of forensic accounting. The scope and content of all subjects are beyond the focus on the law only and provide an opportunity to learn and improve skills in investigative techniques and data collection as well as the skills that are not only able to identify the bad management but also ethical issues and fraudulent activity (www. uow.edu.au), (accessed December 2015).

The subjects provided by the University of Wollongong for the education program can be seen in the table below:
Tabel 2

Subjects in Master of Forensic Accounting Program, University of Wollongong Australia

\begin{tabular}{|l|c|}
\hline \multicolumn{1}{|c|}{ Subject } & Credit \\
\hline Introductory Forensic Accounting & 6 \\
\hline Forensic and Litigation Framework & 6 \\
\hline Fraud and Failure & 6 \\
\hline Investigative Processes & 6 \\
\hline Advanced Investigative Techniques & 6 \\
\hline $\begin{array}{l}\text { Independent Accounting Expert } \\
\text { Reports }\end{array}$ & 6 \\
\hline $\begin{array}{l}\text { Evidence and the Forensic } \\
\text { Accountant }\end{array}$ & 6 \\
\hline $\begin{array}{l}\text { Compliance, Assurance, and } \\
\text { Governance }\end{array}$ & 6 \\
\hline
\end{tabular}

Source: www.uow.edu.au

From the table above, it can be seen that there are several variations of model proposed by West Virginia University. However, these variations do not leave the urgency on the need of the balance between theory and skills in forensic accounting.

\section{Reality of Forensic Accounting Subjects in Indonesia}

The increased need for forensic accounting practitioners, as it has been written, has urged the university, as the provider of professionals, to respond quickly. No exception in Indonesia, the opportunity to open forensic accounting subject in various versions of placement needs to be observed. Here are the results of the survey to the official website of the universities that provide the study program of Accounting (undergraduate program): 


\section{Tabel 1}

Forensic Accounting Subjects at universities in Indonesia

\begin{tabular}{|c|c|}
\hline University & Subject \\
\hline $\begin{array}{l}\text { University of } \\
\text { Gadjah Mada }\end{array}$ & $\begin{array}{l}\text { Forensic } \\
\text { Accounting and } \\
\text { Fraud Investigation } \\
\text { (Prerequisite: Audit 2, } \\
\text { Elective) }\end{array}$ \\
\hline $\begin{array}{l}\text { University of } \\
\text { Brawijaya }\end{array}$ & $\begin{array}{l}\text { Forensic } \\
\text { Accounting and } \\
\text { Fraud Examination } \\
\text { (Concentration in } \\
\text { Business Accounting) }\end{array}$ \\
\hline $\begin{array}{l}\text { University of } \\
\text { Padjajaran }\end{array}$ & $\begin{array}{l}\text { Forensic Accounting } \\
\text { (Elective) }\end{array}$ \\
\hline $\begin{array}{l}\text { University of } \\
\text { Narotama }\end{array}$ & Fraud Examination \\
\hline $\begin{array}{l}\text { Islamic University } \\
\text { of Syarif } \\
\text { Hidayatullah }\end{array}$ & $\begin{array}{l}\text { Audit Investigation } \\
\text { and Forensic } \\
\text { Accounting (Elective } \\
\text { course: Accounting } \\
\text { Examination) } \\
\end{array}$ \\
\hline $\begin{array}{l}\text { University of } \\
\text { Trisakti }\end{array}$ & $\begin{array}{l}\text { Fraud Examination } \\
\text { and Forensic } \\
\text { Accounting (Elective) }\end{array}$ \\
\hline
\end{tabular}

Source: University official website (accessed February 2015)

The table above shows some universities that include forensic accounting in their accounting study program curriculum. The names of universities listed in the table above are part of the top 50 of the 2015 University Web Ranking published on page www.4icu.org. The names of universities that are not included in the above data are deliberately excluded for several reasons, including the fact that some universities / institutes are the providers of specific education programs that do not provide study program of accounting. For example,
Institute of Technology is focusing on science of technology, and public universities that used to be theTeachers' Training College are focusing on science of education, although in their development, some of them also provide bachelor program in accounting. In addition to specific educational program, another reason is the unavailability of sufficient data to draw conclusions on the official website of the universities. Thus, the retrieval of data is only done at universities that provide sufficient data and provide forensic accounting subjects. Some universities do not provide forensic accounting subject in their curriculum.

From the table above, it can be seen that forensic accounting subject has different names among universities. The university that retains the name of forensic accounting is University of Padjadjaran (Unpad). While University of Gadjah Mada (UGM) and Islamic University of Syarif Hidayatullah give the name "Forensic Accounting and Fraud Investigation" and University of Brawijaya (Unibraw) and University of Trisakti give the name "Forensic Accounting and Fraud Examination". West Virginia University (2007) itself does not use the name "forensic accounting" but "Fraud and Forensic Accounting”.

Based on the subject position, University of Brawijaya incorporates forensic accounting subject as a subject of concentration. University of Gajah Mada and University of Padjajaran prefer making the forensic accounting subject as an elective subject. This position has been very good since the introduction to forensic accounting through concentration and elective 
is based on the demand. The demand of the students for the subject reflects a better introduction to the subject itself.

\section{CONCLUSION}

The work done by the West Virginia University (2007) may help pave the way for universities either in the United States or elsewhere in the world to offer forensic accounting subject to students and prospective students. Fraud is the fact in which its evidence is often difficult to find. Therefore, it is necessary to develop the supporting science to find the strong evidence. Strong and undisputed evidence will be an important part of law enforcement and business rescue. Moreover, fraud eradication can be done more scientifically without subjective tendency.

In the forensic accounting curriculum that has been published by West Virginia University, it can be seen that the materials include criminology subject such as legal and regulatory, and professional environment subject suach as business ethics, forensic accounting, and forensic and litigation advisory services. Basically, the subjects, partially or entirely, have been taught in bachelor program, but only criminology that is rarely found in the study program of accounting at university. This subject can be considered to become elective subject, because it helps accountants, at the time of graduation, choose career as a forensic accountant. In bachelor program of accounting, the subject that is usually associated with law is legal aspect in business. But this subject is not able to accommodate the needs of accountants to explore crime, especially in fraud.
The limitation of this study is the absence of surveys or observations on the planning and implementation of forensic accounting curriculum at universities in Indonesia. This article basically just provides a descriptive overview of the publications of West Virginia University (2007) and it still needs to be enriched with data in the field.

It is suggested that future researchers conduct field research on the application of forensic accounting curriculum at universities. If the forensic accounting curriculum, in fact, has not been developed yet, some experts who have completed their doctoral program in the field of forensic accounting can be interviewed to find out the tendency of forensic accounting curriculum development.

\section{REFERENCES}

Davis, Charles., Ramona Farrel., dan Suzanne Ogilby. 2010. Characteristics and Skills of the Forensic Accountant. AICPA

Djalil, Rizal. 2014. Pertimbangan Kualitatif: Pendekatan Baru dalam Audit. Jakarta: RMBOOKS

Enofe, A.O., P.O. Okpako., dan E.N. Atube. 2013. The Impact Forensic Accounting on Fraud Detection. European Journal of Business and Management Vol. 5, No. 26, 2013

Jumansyah. 2014. Persepsi Praktisi Kantor Akuntan Publik dan Akademisi Mengenai Akuntan dan Akuntansi Forensik. Al Hisbah Jurnal Akuntansi Keuangan dan Syariah Volume 2 No. 1, Februari 2014, pg. 1-21 
Kleyman, Yelena. 2006. A Course in Forensic Accounting. Honors College Theses. Paper 40.

Smith, G. Stevenson, dan D. Larry Crumbley. 2009. How Divergent are Pedagogical Views Toward The Fraud/Forensic Accounting Curriculum? Global Perspective on Accounting Education Volume 6, 1-24.

West Virginia University. 2007. Education and Training in Fraud and Forensic Accounting: A Guide for Educational Institutions, Stakeholder Organizations, Faculty and Students. U.S: NCJRS www. uow.edu.au, accessed December 2015 